DOI: https://doi.org/10.3126/tgb.v6i0.26169

\title{
Community Based Disaster Risk Management: A Case Study of Mahakali River Basin, Kanchanpur
}

\author{
Raj Kumar Pariyar1
}

\begin{abstract}
Kanchanpur district is one of the disaster-prone districts identified by Nepal Risk Reduction Consortium (NRRC). Every year the community of Kanchanpur district are affected by multi-disaster primarily flood. The most communities are highly vulnerable due to the poverty, disadvantage caste and ethnicity, hazard, education etc. This study endeavour to explore the status of community initiative to build up disaster resilient. This study covers 10 villages of Mahakali river basin in Kanchanpur district. The villages are under the process of disaster resilience through establishing Community Disaster Management Committee $(C D M C)$, who supports to get access to disaster risk reduction (DRR) information, vulnerability and capacity assessment and developing trained man power for preparedness and response.
\end{abstract}

Key-words: Mahakali river basin, community, community-based disaster risk reduction, vulnerability, capacity, resilient.

\section{Introduction}

Community-based disaster risk reduction is a practical approach that supports community efforts to increase their own disaster resiliency and allows them to better withstand the impacts of disasters, (NRRC, Flagship Programme, 2013). It has been seen that community-based disaster management (CBDM) is very popular term in later 1980s and 1990s, which gradually evolved to community-based disaster risk management (CBDRM) and then, to community-based disaster risk reduction (CBDRR). CBDRM and CBDRR are often used with similar meaning, with enhanced focus on "risk". However, there still exists a thin line of distinction (Habiba, Shaw and Abedin, 2013). Disaster risk reduction focuses more on reducing underlying risk, encouraging preventive action before a disaster. Disaster risk management, in contrast, focuses on broader aspects of disaster issues, from prevention and mitigation to relief, response, and recovery. Communities are the

${ }^{1}$ Corresponding e-mail: rajpariyar2012@gmail.com 
first responders in case of a disaster. Therefore, community-based disaster risk reduction (CBDRR) should be the core of any risk reduction approach (Shaw, 2016).

CBDRR commence in Nepal when Nepal Government made commitment to the international document the Hyogo Framework for Action 2005. The Hyogo Framework of Action (HFA) 2005-2015 is a consensus document adopted at the UN World Conference on Disaster Reduction, Kobe in 2005, towards achieving the stated goals of DRR within the stipulated time frame (NSDRM, 2009).

Figure 1: Process of emerging community resilient characteristics

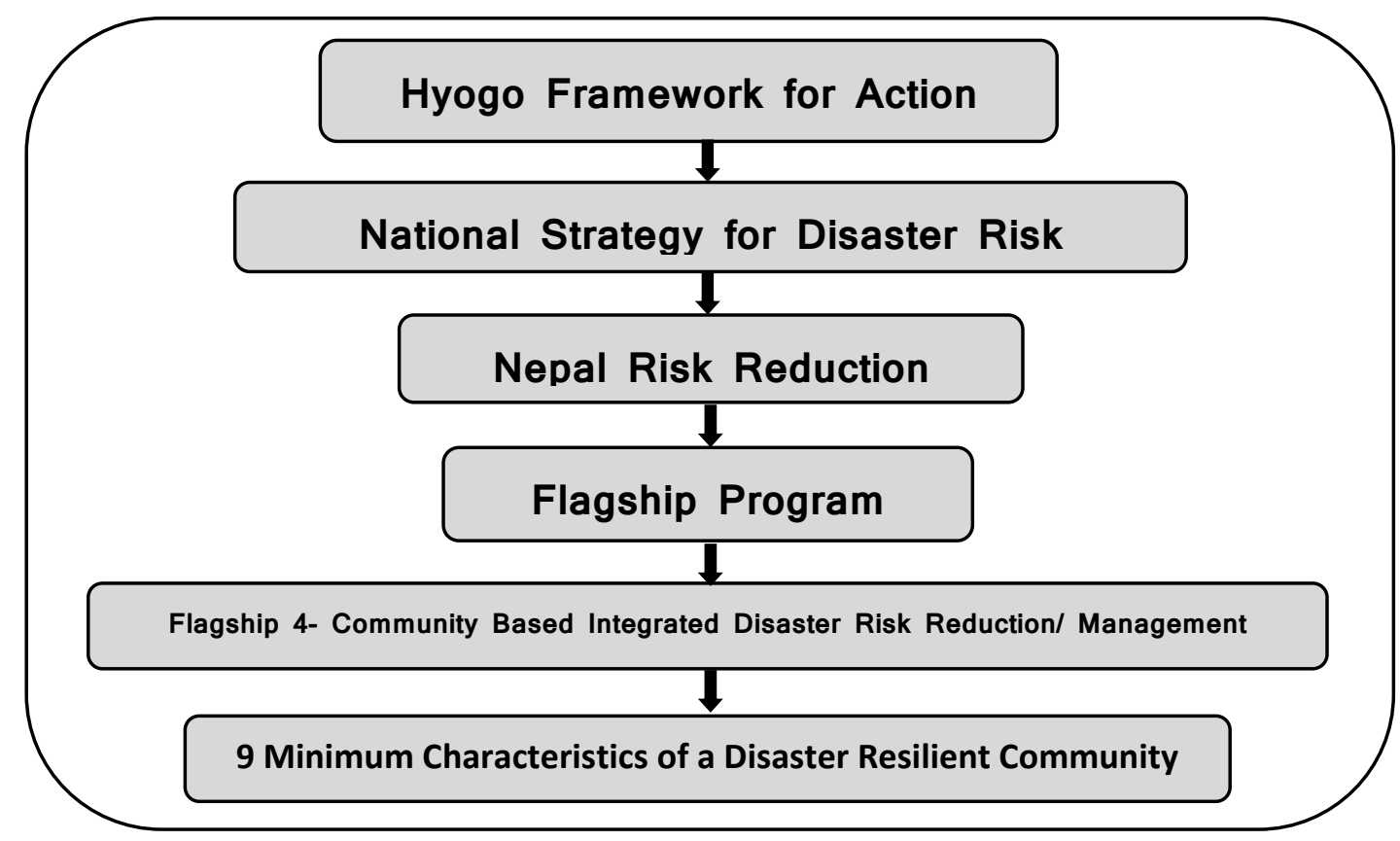

National Strategy for Disaster Risk Management (NSDRM), 2009 developed in Nepal addressing the agenda of Hyogo Framework for Action (HFA). Similarly, in 2009 the Nepal Risk Reduction Consortium was formed to support the Government of Nepal in developing a long-term DRR Action Plan building on the NSDRM. Based on Government priorities and discussions with multi stakeholder groups during 2009, the Consortium members and government identified five flagship areas of immediate action for disaster risk management in Nepal (NRRC, 2013).

Out of five flagships identified by NRRC, flagship 4 - Community Based Integrated Disaster Risk Reduction/ Management is one of the important areas covering the feeling of community resilient characteristics (Figure 1). Flagship 4 seeks to capitalise on the Community Based Disaster Risk Reduction/ Management 
activities and experience already accumulated by organisations, to create a more consistent and systematic approach to CBDRR/M at Village Development Committee (VDC)/municipality level. By following a set of minimum characteristics for disaster resilient communities and adopting a package of common elements to be included in all CBDRR interventions, the Flagship aims that communities receive consistent support and will enable more effective tracking of progress in VDCs / municipalities across the country (Flagship 4 Handbook, 2013).

In the course of implementation of a set of characteristics, it has tried to include all socially excluded groups and people of geographically remote area aiming the impower with the heart of decision making and implementation, monitoring and evaluation of disaster risk management activities. The bottom line of inclusive CBDRM is everybody is safer, and no one is left out.

\section{Methodology}

\section{Study area}

Kachanpur district lies in Sudur Pashchim province which spreads $28^{\circ} 35^{\prime \prime}$ north to $29^{\circ} 08^{\prime \prime}$ north latitude and $80^{\circ} 25^{\prime \prime}$ east to $80^{\circ} 33^{\prime \prime}$ east longitude (DPRP Kanchanpur, 2069). During 2010, Flagship 4 consultation meetings identified the most vulnerable 47 districts in Nepal based on secondary data. This data included the Nepal MultiHazard Scenario Assessment and the Nepal Vulnerable Districts to Disasters, 19712007 (NRRC, Flagship Programme, 2013). Kanchanpur district is one of the vulnerable districts of 47 identified by Flagship 4 . The different 10 villages of Kanchanpur have been selected for this study. The villages where vulnerable communities live adjoining with the Mahakali River basin, including marginalized groups, persons with disabilities, and the elderly people highly affected by the risks posed by natural hazards. The Mahakali River is one of the largest rivers of Nepal, marking the border between Nepal and India. The river flood annually affects the study villages. Kanchanpur districts experienced major flooding in 2013, that affected thousands of people and damage huge properties damage (Table 1). 


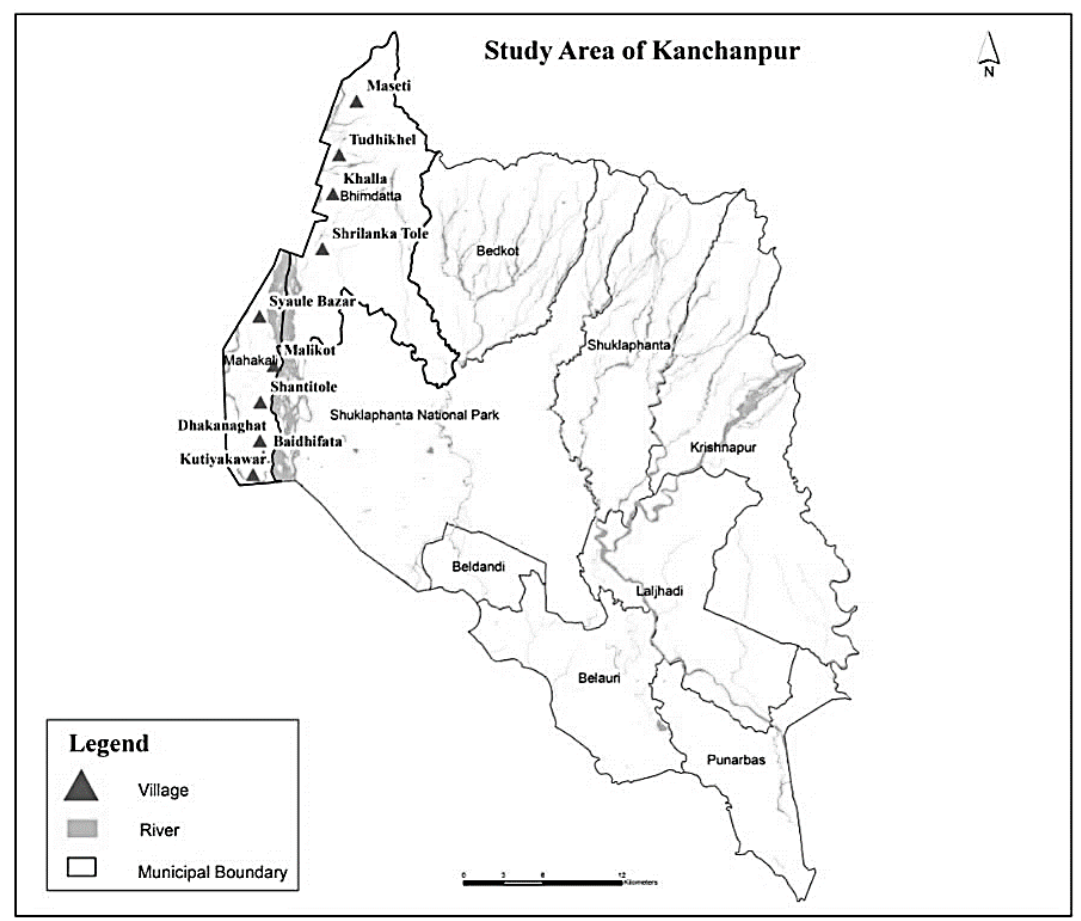

Figure 2: Study villages of Mahakali River Basin, Kanchanpur

\section{Tools and techniques}

Checklist was used to collect socio-economic and other data was carefully observed community disaster risk management committee structure and collected data of hazard ranking, capacity assessment, assess the trained human resources on response and preparedness. GIS has been used to locate the 10 villages of study area. Key informant interview was conducted with the key portfolios and members of CDMCs. Likewise, six focus group discussions were conducted with the participation of CDMC members, community people including person with disability, senior citizen, single women, Dalits, Janajatis and BCTS. Focus group discussions aimed to draw the insights of community facing multiple disasters and societal coping abilities, as well as human knowledge, skills and collective attributes such as social relationships, leadership and management. The total household of Kanchanpur district is 60158 (DPRP, Kanchanpur, 2069) where the study area covers 923 shares $1.53 \%$. The collected different data were tabulated and analysed in Microsoft Excel.

The community disaster risk management plan developed by CDMC were reviewed to understand the context of each community in the studied area. District 
Disaster Preparedness and Response Plan of Kachanpur were reviewed to be sensitized the overall scenario of disaster, different stakeholders' responsibilities for disaster response.

Table 1: Major incidents and number of losses/damages in Kanchanpur

\begin{tabular}{|c|l|r|}
\hline SN & \multicolumn{1}{|c|}{ Incidents } & Numbers \\
\hline 1 & Total death & 385 \\
\hline 2 & Missing people & 25 \\
\hline 3 & Affected family & 71062 \\
\hline 4 & Estimated loss & 47600500 \\
\hline 5 & Injured & 5044 \\
\hline 6 & Private house fully damaged & 1664 \\
\hline 7 & Private house partially damaged & 2776 \\
\hline 8 & Cattles loss & 42 \\
\hline 9 & Displaced shed & 43 \\
\hline
\end{tabular}

Source: Desinventar data and ministry of home affairs, Nepal, 2018

\section{Results and discussion}

\section{Organisational base at municipality, ward and community level}

Nepal Government recently has revised the Local Disaster Risk Management Plan (LDRMP) and drafted Local Disaster and Climate Resilient Plan Guideline (LDCRP). As per the provision mention in LDCRP guideline, there has been formed CDMC in all 10 villages of study area. CDMC take responsibility of implementation DRR activity and sustainability. CDMC has its guideline to form with specific standard of structure and; roles and responsibility. Disaster Management Committees are comprised of at least 11 members nominated by the community; with each committee have at least $40 \%$ membership of women and marginalised groups. For the sustainability of committee, an elected ward member and a member of Sub-Chapter from Nepal Red Cross Society is also mandatory. In addition, socially excluded groups such as Dalit, Janajatis, person with disability, senior citizen, single women need to be included in the committee. 
Table 2: Village wise member in CDMC

\begin{tabular}{|l|r|r|r|r|r|r|r|}
\hline \multirow{2}{*}{ Community } & \multicolumn{6}{|c|}{ Disintegrated Number of Community Member } \\
\cline { 2 - 9 } & Male & Female & Total & Dalit & Janajati & BCTS & Total \\
\hline Musetti & 6 & 5 & 11 & 1 & & 10 & 11 \\
\hline Tudikhel & 8 & 3 & 11 & 4 & 2 & 5 & 11 \\
\hline Khalla & 7 & 4 & 11 & 4 & 1 & 6 & 11 \\
\hline Shrilanka & 5 & 6 & 11 & 10 & & 1 & 11 \\
\hline Syaule Bazar & 6 & 5 & 11 & 6 & & 5 & 11 \\
\hline Malika & 5 & 6 & 11 & 3 & & 8 & 11 \\
\hline Shanti & 3 & 8 & 11 & 6 & 5 & & 11 \\
\hline Dhakanaghat & 3 & 8 & 11 & 6 & & 5 & 11 \\
\hline Baidifanta & 2 & 9 & 11 & 5 & & 6 & 11 \\
\hline Kutiyakavar & 4 & 7 & 11 & 6 & & 5 & 11 \\
\hline
\end{tabular}

Source: Field survey, 2018

\section{DRR information initiatives}

Mahakali River flows from Darchula to Baitadi, Dadeldhura and Kanchanpur. There are few hydrological and metrological station which monitor weather condition and disseminate the message to downstream community. There are two-gauge stations in Dattu of Darchula and Parigaun of Dadeldhura for river gauge reading. The assigned person for gauge reading water records the level of Mahakali river frequently and if it is above the warning level then flow the message to downstream community and District Emergency Operation Centre. The Coordinator of Early Warning System Task Force of each community get the information of flood if the water is over the warning level. The Coordinator of Early Warning System Task Force is responsible to disseminate message to the community members in the village through the different devices. Each community has Siren which can be aired high pitch sound around two kilometres. Similarly, there is provision of hand mike. Both devices can be used at the time of disaster to alarm and to keep people prepared to avoid possible effect of disaster.

In each community at least one member has got the training of early warning system. The community office has collected the emergency number of ambulances, hospital, responders, security forces etc. that can be used at the time of disaster for search and rescue; first aid and safe evacuation. The DRR message also airs from the local FM to raise the awareness and sensitization on disaster focusing secured

2 BCTS=Brahmin, Chhetri, Thakuri, Sanyasi 
belongings, preparing dried food, identifying safe spaces, and also inform about how to reduce the risk of health hazards after a flood, e.g. boiling drinking water. Community has planned to establish Disaster Learning Centre (DLC) covering the surrounding community to learn and share the DRR related information. Regular simulation on early warning system also provide the information that how community get disaster information and how to be safe following the message. Unfortunately, three communities of northern part of Mahakali river in Kanchanpur have no access of telephone and mobile services from Nepal. The people from Museti, Tudikhel and Khalla use Indian mobile to community in Nepal. Which is a barrier of communication at the time of disaster for immediate external services.

\section{Multi-hazard risk and capacity assessments}

All community have done vulnerability and capacity assessment (VCA). The major risks, hazards, vulnerability and capacity of community identify through the process of VCA (Table 3). There is participation of women, Dalit, janajati, person with disability, single women, senior citizen and children to come out their insights of disaster that can be used to identify real problem and experience to develop demand driven community disaster management planning.

Table 3: Community wise hazards identified by VCA

\begin{tabular}{|l|l|l|l|}
\hline \multirow{2}{*}{ Community } & \multicolumn{3}{c|}{ Hazards } \\
\cline { 2 - 4 } & First Ranked & \multicolumn{1}{c|}{ Second Ranked } & \multicolumn{1}{c|}{ Third Ranked } \\
\hline Musetti & Flood & Unsafe Dirking Water & Wildlife Attack \\
\hline Tudikhel & Flood & Drought & Lack of Drinking Water \\
\hline Khalla & Flood & Wildlife Attack & Prolapse \\
\hline Shrilanka & Flood & Open Domestic Animal & Wildlife Attack \\
\hline Syaule Bazar & Flood & Open Domestic Animal & Cold -Wave \\
\hline Malika & Flood & Drought & Open Domestic Animal \\
\hline Shanti & Flood & Wildlife Attack & Open Domestic Animal \\
\hline Dhakanaghat & Flood & Water Induced Disease & Windstorm \\
\hline Baidifanta & Flood & Wildlife Attack & Fire \\
\hline Kutiyakavar & Flood & Water Induced Disease & Malaria \\
\hline
\end{tabular}

Source: Field survey, 2018

As the result of VCA, flood is most important hazard in all community. Since all the studied villages are adjacent with Mahakali river from top to bottom, community always stricken by flood which are as the first ranked hazards. As the second ranke hazards, three communities have wild life attack as the risk. Each pair of the six 
communities have the risk of water induced disease, drought and open domestic animal respectively. Similarly, unsafe drinking water is the second ranked hazards in one community. In term of capacity, almost each community has open space for safe evacuation, at least one school for emergency shelter, few people who can swim, health centre and securities. After developing the Community Disaster Management Plan (CDMC) on the basis of VCA, local government and development partner extended hands to support execution of those plans. Consequently, Mahakali municipality shared the cost for bio-engineering to protect the river cutting by Jogbudha river in Kutiyakabar. Likewise, Bhimdatta municipality shared cost to construct culvert in a revolute in Shrilanka tole.

\section{Community preparedness and response teams}

Before the introduction of CBDRM in Nepal, a set of search and rescue, first aid team and other relief team had to go disaster affected community for response. The team usually departed from district headquarter. It could take long time, sometime few days to get the community. During the time of traveling from distant people would die and the situation would worsen. So, the main importance of community preparedness and response team is to take action immediately the disaster happen. Community is the first responder at a time of disaster. Professional responders may take time getting the disaster affected community therefore community responder generally work as a bridge unless the professional handling situation. Thence, training and skill is important for community people.

CDMC has the different six task forces which is guided by LDRMP guideline 2068 BS. The task force includes i) Information and early warning systems ii) Search and rescue iii) Relief management and rehabilitation iv) First aid v) Damage assessment and need analysis and vi) Gender equality and protection. Different task forces as the guideline have been formed in all 10 communities of study area.

Table 4: Community wise trained human resource

\begin{tabular}{|c|c|c|c|}
\hline \multirow[t]{2}{*}{ Community } & \multicolumn{3}{|c|}{ No. of trained human resources } \\
\hline & CADRE & First aid & Early warning \\
\hline Musetti & 5 & 6 & 2 \\
\hline Tudikhel & 6 & 5 & 1 \\
\hline Khalla & 7 & 6 & 1 \\
\hline Srilanka & 6 & 6 & 1 \\
\hline Syaule Bazar & 3 & 8 & 1 \\
\hline Malika Tole & 4 & 8 & 1 \\
\hline
\end{tabular}




\begin{tabular}{|l|r|r|r|} 
Shanti Tole & 5 & 8 & 1 \\
\hline Dhakanaght & 4 & 8 & 1 \\
\hline Baidhifata & 4 & 8 & 1 \\
\hline Kutiyakawar & 4 & 7 & 1 \\
\hline Total & 48 & 70 & 11 \\
\hline
\end{tabular}

Source: Field survey, 2018

The member of search and rescue task force are trained on basic course of Community Action for Disaster Response (CADRE). The course comprises the practical skills on search and rescue, first aid etc. As of the date of August 2018, there are total 48 people who have got training on CADRE and upgraded themselves as a responder. In addition, 70 members from first aid task force have got training on first aid. Likewise, 11 members from information and early warning systems task force are trained on early warning system. The key responsibility of early warning task force is to disseminate the message of possible disaster specially flood.

\section{Conclusion}

Kanchanpur is one of the flood disaster prone districts of Nepal. Particularly, due to the Mahakali river, people who live nearby to river are highly vulnerable. For ages community lost human and physical assets at the time of monsoon. Over the time, community have strengthened their knowledge, skill and behaviour to avoid the adverse impact of disaster. People from the studied area are on the process to build up disaster resilient community through community-based disaster risk management model.

All ten villages have CDMC in inclusive approach considering gender equality and social inclusion. The CDMC is responsible for identifying the risk of community, planning to minimise the risk, implementation DRR activities and monitoring. Community has the access of DRR information through different approach such as local FM, vulnerability and capacity map placed in public accessibility. Regular simulation on specific disaster including early warning messaging. Sharing DRR related information through different mass gathering- meetings, workshop, training and orientation. Some of the communities in northern part of Mahakali river have not the access of mobile phone. People have to communicate using Indian mobile services which in some extent is not easy in terms of cost and authentication. Likewise, all 10 villages have done the VCA. It has been carried out through the participation of community including all vulnerable community live within the village. As per the VCA result, flood is in the first rank hazard of all villages. Beside 
flood, unsafe dirking water, drought, wildlife attack, open domestic animal and water induced disease are the second and third ranked hazards. All village's CDMCs have been started to reduce vulnerability through different interventions of mitigation, awareness training, emergency fund, early warning system. Schools, government offices, open space, natural resources-river, forest, land are the main capacities of community. All community have trained man power in CADRE, first and early warning system. Through these community initiatives, it seems to have the community is under the process of disaster resilience.

\section{References}

District Disaster Relief Committee (2069 BS). Disaster preparedness and response plan. Kanchanpur: Government of Nepal.

Habiba, U., Shaw, R., and Abedin, A, Md. (2013) Community-based disaster risk reduction approaches in Bangladesh. DOI 10.1007/978-4-431-54252-0_12, Japan: Springer.

Ministry of Home Affairs (2009). National strategy for disaster risk management (NSDRM) 2009. Kathmandu: Government of Nepal.

Ministry of Home Affairs (2017). Nepal disaster report 2017. Kathmandu: Government of Nepal.

Ministry of Local Development (2068 BS). Local disaster risk management planning guideline (LDRMP). Kathmandu: Government of Nepal.

Government of Nepal. Nepal disaster risk reduction portal, Government of Nepal, Kathmandu. http://drrportal.gov.np/

NRRC (2013). Nepal risk reduction consortium flagship programmes. Nepal Risk Reduction Consortium (NRRC).

NRRC (2013). Nepal risk reduction consortium, flagship 4 handbook, Nepal's 9 minimum characteristics of a disaster resilient community. Kathmandu: Nepal Risk Reduction Consortium.

Shaw, R. (2016). Community-based disaster risk reduction. Oxford Research Encyclopaedia of Natural Hazard Science. http:/ / naturalhazardscience.oxfordre.com/ view/10.1093/acrefore/9780199389407.001.0001/acrefore-9780199389407-e47?print $=$ pdf. 